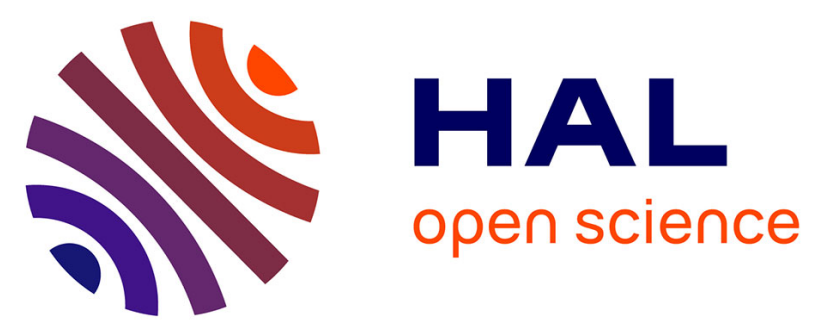

\title{
Distinctive 13C isotopic signature distinguishes a novel sea ice biomarker in Arctic sediments and sediment traps
}

Simon T. Belt, Guillaume Masse, Lindsay L. Vare, Steven J. Rowland, Michel Poulin, Marie-Alexandrine Sicre, Makoto Sampei, Louis Fortier

\section{- To cite this version:}

Simon T. Belt, Guillaume Masse, Lindsay L. Vare, Steven J. Rowland, Michel Poulin, et al.. Distinctive 13C isotopic signature distinguishes a novel sea ice biomarker in Arctic sediments and sediment traps. Marine Chemistry, 2008, 112 (3-4), pp.158 - 167. 10.1016/j.marchem.2008.09.002 . hal-03427331

\section{HAL Id: hal-03427331 \\ https://hal.science/hal-03427331}

Submitted on 18 Nov 2021

HAL is a multi-disciplinary open access archive for the deposit and dissemination of scientific research documents, whether they are published or not. The documents may come from teaching and research institutions in France or abroad, or from public or private research centers.
L'archive ouverte pluridisciplinaire HAL, est destinée au dépôt et à la diffusion de documents scientifiques de niveau recherche, publiés ou non, émanant des établissements d'enseignement et de recherche français ou étrangers, des laboratoires publics ou privés. 
Distinctive ${ }^{13} \mathrm{C}$ isotopic signature distinguishes a novel sea ice biomarker in Arctic sediments and sediment traps

Simon T. Belt a, ${ }^{\text {, }}$, Guillaume Massé a, Lindsay L. Vare a, Steven J. Rowland a, Michel Poulin $^{b}$, Marie-Alexandrine Sicre ${ }^{\mathrm{c}}$, Makoto Sampei ${ }^{\mathrm{d}}$, Louis Fortier ${ }^{\mathrm{d}}$

a Petroleum and Environmental Geochemistry Group, School of Earth, Ocean and Environmental Sciences, University of Plymouth, Drake Circus, Plymouth, Devon, PL4 8AA, UK

b Research Division, Canadian Museum of Nature, PO Box 3443 Station D, Ottawa, Ontario, K1P 6P4, Canada

c Laboratoire des Sciences du Climat et de l'Environnement, Domaine du CNRS, Avenue de la Terrasse, Bat.12, 91198 Gif-sur-Yvette Cedex, France

d Québec-Océan, Université Laval, Quebec, Quebec, G1K 7P4, Canada

* Author for correspondence

Professor Simon T Belt

Petroleum and Environmental Geochemistry Group, School of Environmental Sciences, University of Plymouth, Drake Circus, Plymouth,

Devon,

PL4 8AA,

UK

Tel $+44(0) 1752233042$

FAX: +44 (0)1752 232406

e-mail: sbelt@plymouth.ac.uk 


\begin{abstract}
A $\mathrm{C}_{25}$ highly branched isoprenoid (HBI) monoene hydrocarbon, designated $\mathrm{IP}_{25}$, has been proposed previously to originate from diatoms living in Arctic sea ice, while the presence of $\mathrm{IP}_{25}$ in sediments has been suggested to be a proxy for the occurrence of former Arctic sea ice. Here, we show that the ${ }^{13} \mathrm{C}$ isotopic composition of $\mathrm{IP}_{25}$ in sea ice, in sediment trap material collected under sea ice, and in high latitude northern sediments, is distinctive (isotopically 'heavy') and distinguishable from that of organic matter of planktonic or terrigenous origin. Mean $\delta^{13} \mathrm{C}$ values for $\mathrm{IP}_{25}$ were $-22.3 \pm 0.4 \%$ (sea ice), $-19.6 \pm 1.1 \%$ (sediment traps) and $-19.3 \pm 2.3 \%$ (sediments). These measurements, therefore, support further the proposed use of $\mathrm{IP}_{25}$ as an Arctic sea ice proxy.
\end{abstract}

Keywords: Arctic, Isotopes, Biomarker, $\mathrm{IP}_{25}, \delta^{13} \mathrm{C}$, Sea Ice, Sediment. 


\section{Introduction}

An overview of $I P_{25}$ - an organic geochemical sea ice proxy

Highly branched isoprenoid (HBI) alkenes are ubiquitous biomarkers found in a wide range of marine sediments (e.g. Robson and Rowland, 1986; Rowland and Robson, 1990; Belt et al., 2000a; Sinninghe Damsté et al., 2004). HBIs occur mainly as sester$\left(\mathrm{C}_{25}\right)$ and triterpenoids $\left(\mathrm{C}_{30}\right)$ with between 1-6 double bonds (Volkman et al., 1994; Belt et al., 1996, 2000a, 2001a; Wraige et al., 1997; Grossi et al., 2004). In recent years, structures and source organisms (diatoms) of many HBIs have been reported (Volkman et al., 1994; Belt et al., 2001b,c; Grossi et al., 2004), along with studies of their biosynthesis (Massé et al., 2004), reactivity (Robson and Rowland, 1988; Belt et al., 2000b) and factors affecting the distribution of individual isomers in microalgae (Wraige et al., 1998; Rowland et al., 2001; Belt et al., 2002). In the latter case, a strong dependence of $\mathrm{C}_{25} \mathrm{HBI}$ unsaturation on growth temperature was noted for one of the source diatoms Haslea ostrearia (Gaillon) Simonsen, with less unsaturation with decreasing temperature (Rowland et al., 2001). Since other Haslea species have been reported to inhabit Arctic sea ice (Poulin, 1990; Booth and Horner, 1998), it was postulated that less unsaturated isomers may therefore be produced by sea ice diatoms and, if these isomers were then also present in sediments below sea ice, it was hypothesized further that they could be used as proxies for the former presence of sea ice (Belt et al., 2007). Consistent with this hypothesis, we reported recently on the presence of a mono-unsaturated HBI alkene in Arctic sea ice and in Arctic sediments, the oldest of which was dated to be at least 9,000 years old (Belt et al., 2007). The structure of the alkene was determined using NMR spectroscopy and by independent 
synthesis. We proposed the term $\mathrm{IP}_{25}$ (Ice Proxy with 25 carbon atoms) for this compound (Fig. 1; compound 1) to distinguish it from other HBI isomers. Since $\mathrm{IP}_{25}$ has thus far not been reported in sediments from more temperate environments, or indeed from northern high latitude open-water or ice-free phytoplankton, we suggested its presence in high latitude sediments to be specific to a sea ice origin (Belt et al., 2007). Indeed, we used the abundance of $\mathrm{IP}_{25}$ occurrence in a marine sediment core from the North Icelandic Shelf to reconstruct a palaeo sea ice record for much of the last 1,000 years. The $\mathrm{IP}_{25}$ data were remarkably consistent with historical sea ice records and with other palaeoclimatic parameters (Massé et al., 2008).

\section{Stable isotope $\left(\delta^{13} C\right)$ composition as a measure of sea ice origin}

In a number of empirical studies, analysis of the stable isotope $\left(\delta^{13} \mathrm{C}\right)$ composition of organic matter $(\mathrm{OM})$ extracted from polar sea ice has revealed an enrichment in ${ }^{13} \mathrm{C}$ relative to ${ }^{12} \mathrm{C}$ (Gibson et al., 1999; McMinn et al., 1999; Thomas et al., 2001; Kennedy et al., 2002; Stein and Macdonald, 2004; Drenzek et al., 2007). Typically, the resultant $\delta^{13} \mathrm{C}$ values for sea ice-derived $\mathrm{OM}$ have been found to lie within the range of $-5 \%$ to $-20 \%$, whereas the related values for open-water, or phytoplanktonderived OM typically lie within the range of $-22 \%$ to $-30 \%$ (Kennedy et al., 2002; Drenzek at al., 2007). Although outliers probably exist, the separation of these ranges suggests that distinguishing $\mathrm{OM}$ of sea ice origin from that biosynthesized by openwater phytoplankton should be straightforward and, furthermore, should be useful when attempting to determine the origins of organic geochemicals found in sediments. To date, the majority of stable isotope analyses have been carried out on sea icederived OM from the Antarctic, and these studies have been conducted on bulk OM rather than on individual compounds. For example, McMinn et al. (1999) analyzed 
the lower $5 \mathrm{~cm}$ of fast ice from McMurdo Sound, Antarctica and found the OM to be relatively enriched in ${ }^{13} \mathrm{C}\left(\delta^{13} \mathrm{C}=-12 \%\right.$ to $\left.-18 \%\right) .{ }^{13} \mathrm{C}$-enrichment has also been observed by Kennedy et al. (2002) for OM in sea ice from the Weddell Sea, and by Thomas et al. (2001) and Gibson et al. (1999) for particulate OM obtained from sediment traps from the eastern Weddell Sea and Prydz Bay, Antarctica, respectively. The relative enrichment of ${ }^{13} \mathrm{C}$ has often been attributed to the restricted access of sea ice photosynthetic organisms to $\mathrm{CO}_{2}$. Reductions in $\mathrm{CO}_{2}$ concentrations are thought to occur in sea ice due to limited exchange between the sea ice and the underlying seawater. This hypothesis is certainly consistent with the $\delta^{13} \mathrm{C}$ values of algal-derived OM when microalgae are grown under $\mathrm{CO}_{2}$-limiting conditions (Wada et al., 1987; Fischer 1991; Rau et al., 1991). However, the relationship between $\delta^{13} \mathrm{C}$ and 'available' $\mathrm{CO}_{2}$ is probably not straightforward since some of the most ${ }^{13} \mathrm{C}$-enriched $\mathrm{OM}$ in sea ice has been found in relatively exposed ice conditions where $\mathrm{CO}_{2}$ exchange would be expected to be relatively facile (Kennedy et al., 2002). It is likely, therefore, that there are also phenotypic controls governing the $\delta^{13} \mathrm{C}$ values that are currently not well understood. In addition, the extent of stable isotope fractionation is also associated with cell growth rates (e.g. Pancost et al., 1997; Popp et al., 1998); this too needs to be considered when interpreting $\delta^{13} \mathrm{C}$ data. Nonetheless, the clear empirical relationship between the ranges of $\delta^{13} \mathrm{C}$ values and the origins of marine OM (sea ice versus open-water phytoplankton) remains, for the Antarctic, at least. Similar to the studies of Antarctic samples, in the Arctic region, analysis of the carbon isotopic composition of sedimentary material has been limited largely to the analysis of bulk OM (reviewed by Stein and Macdonald, 2004) although a few more compound specific studies have appeared recently for both polar regions (Drenzek et al., 2007; Sinninghe Damsté et al., 2007). On the basis of an albeit small number of 
previous measurements, $\delta^{13} \mathrm{C}$ values for Arctic sea ice-derived OM (e.g. $-15 \%$ o to $-21 \%$ ) appears to be have a somewhat different isotopic range to that commonly reported for biomass in Southern Hemisphere sea ice (e.g. $-5 \%$ o to $-20 \%$ ). However, whether these few measurements are representative of ${ }^{13} \mathrm{C}$ values of sea ice $\mathrm{OM}$ from northern high latitudes in general, is questionable, and in need of further investigation. In the present study, we therefore determined the isotopic composition of a known sea ice specific biomarker $\left(\mathrm{IP}_{25}\right)$ in samples of sea ice, in $\mathrm{OM}$ from sediment traps below sea ice and in northern high latitude sediments. We made comparisons with the $\delta^{13} \mathrm{C}$ values of other co-occurring hydrocarbons (e.g. $n$-alkanes) and bulk OM in order to better understand the contributions that sea ice-derived OM might make to Arctic sediments. We propose that the distinctive isotopic signature of $\mathrm{IP}_{25}$ produced in sea ice and found in sediment traps and in sediments, is further evidence of the utility of this compound as a sea ice proxy (c.f. Belt et al., 2007).

\section{Experimental}

\subsection{Sea ice, sediment trap and sediment sampling}

Sea ice sampling was conducted in May 2004 on first-year land-fast ice in Franklin Bay (Fig. 2). Cores were collected with a Mark II ice corer (9 $\mathrm{cm}$ internal diameter, Kovacs Enterprises). The bottom $5 \mathrm{~cm}$ of each core was immediately cut with a stainless steel saw and stored in isothermal metallic containers which were then transferred and stored at $-80^{\circ} \mathrm{C}$. Subsequently, sea ice samples were analyzed for HBI content as described previously (Belt et al., 2007). Surface sediment material (NOW-1 and NOW-2) was obtained from the Geological Survey of Canada (Atlantic Division, Bedford Institute of Oceanography, Dartmouth, Nova Scotia). Combinations of 
surface sediment (box core), trigger weight cores (TWC) and piston cores (PC) were obtained from six locations (ARC-1 - ARC-6; Fig. 2, Table 1) during the AugustSeptember 2005 ArcticNet expedition of the CCGS Amundsen across the Canadian High Arctic. Further details on the core locations are given elsewhere (Belt at al., 2007). Sediment traps, deployed in Franklin Bay (July 2004) during the 2003-2004 Canadian Arctic Shelf Exchange Study (CASES) were retrieved during the 2005 ArcticNet expedition. A 26-cup time-programmed (1-4 week intervals) sediment trap was deployed at ca. $200 \mathrm{~m}$ from mid-July 2004 to mid-August 2005 at a mooring site (ca. $250 \mathrm{~m}$ bottom depth) in Franklin Bay. A more detailed account of the sediment trap sample collection procedure can be found in Forest et al. (2008). Stable isotope $\left(\delta^{13} \mathrm{C}\right)$ measurements on the bulk OM in the sediment trap material were performed according to the methods of Fernandes and Sicre (2000).

\subsection{Lipid analysis}

Extraction of hydrocarbon lipids from sea ice, sediments and sediment trap material together with quantification of individual compounds by gas chromatography - mass spectrometry (GC/MS) was carried out as described previously (Belt et al., 2007). For selected samples that contained sufficient abundances of $\mathrm{IP}_{25}$, other HBIs and $n$-alkanes, extracts were further analyzed in triplicate by gas chromatographycombustion-isotope ratio mass spectrometry (GC/C/IRMS) using the Natural Environment Research Council (NERC, UK) Life Sciences Mass Spectrometry Facility at the University of Bristol (Application LSMSFBRISTOL007). $\delta^{13} \mathrm{C}$ determinations (\%o) are reported here as referenced to the Vienna Pee-Dee Belemnite (VPDB) standard. 


\section{Results}

\subsection{Sea ice samples}

We previously reported the occurrence of the sea ice biomarker $\operatorname{IP}_{25}(1 ;$ Fig. 1$)$ in sea ice samples from Hudson Bay, McDougall Sound (near Resolute) and Franklin Bay (Fig. 2; Belt et al., 2007). For the current study, GC/MS analysis of the hydrocarbon extract obtained from a sea ice sample from Franklin Bay showed the presence of $\mathrm{IP}_{25}$ as a major component (Fig. 3). Subsequent analysis of this extract by GC/C/IRMS gave a $\delta^{13} \mathrm{C}$ value of $-22.3 \%$ for $\mathrm{IP}_{25}$ (Fig. 4). Chromatographic overlap with other compounds prevented us from carrying out similar measurements for extracts obtained from Hudson Bay or McDougall Sound. The hydrocarbon fraction from the Franklin Bay sea ice sample extract also contained a suite of $n$-alkanes whose $\delta^{13} \mathrm{C}$ values ranged from about $-26 \%$ to $-30 \%$ (Fig. 4).

\subsection{Sediment trap samples}

Sediment trap samples from Franklin Bay (Fig. 2) were analyzed in two ways. Firstly, $\delta^{13} \mathrm{C}$ values were determined for bulk OM from sediment trap samples collected from August 2004 to mid-July 2005 at one-, two- or four-weekly intervals (Fig. 5). These $\delta^{13} \mathrm{C}$ values ranged from ca. $-25.0 \%$ to $-26.5 \%$ for the majority of the sampling periods, with the exception of mid-late May, where the $\delta^{13} \mathrm{C}$ value increased to about $-23.5 \%$. In a second set of measurements, we determined the abundances and $\delta^{13} \mathrm{C}$ values of $\mathrm{IP}_{25}$ in some of the trap samples (November 2004 - June 2005) as a potentially more reliable indicator of the isotopic composition of sea ice-derived OM than bulk OM values. When analyzed by GC/MS, $\mathrm{IP}_{25}$ was found to be present in all of these sediment trap samples (Fig. 3), with an elevated abundance during May (Fig. 
5). Where abundance and chromatographic separation permitted, $\delta^{13} \mathrm{C}$ values for $\mathrm{IP}_{25}$ were measured and found to be higher than the bulk OM in all cases, with a mean value of $-19.6 \pm 1.1 \%$ o $(n=11$; Fig.5). The sediment trap samples also contained $n$ alkanes. Of those samples that were sufficiently abundant for $\delta^{13} \mathrm{C}$ measurement $\left(\mathrm{C}_{19}\right.$ $-\mathrm{C}_{31}$; Fig. 4; Table 1), the $n$-alkanes were all found to be relatively depleted in ${ }^{13} \mathrm{C}$ compared to either the bulk $\mathrm{OM}, \mathrm{IP}_{25}$ or the $n$-alkanes found in the sea ice sample from the same location, with $\delta^{13} \mathrm{C}$ values ranging from $-29.7 \%$ o to $-32.3 \%$. Finally, the sediment trap OM obtained from July 2005 (after the major ice melt) also contained $n-\mathrm{C}_{21: 6}$ from planktonic diatoms (Blumer et al., 1971; Yunker et al., 1995) and this compound was also depleted in ${ }^{13} \mathrm{C}\left(\delta^{13} \mathrm{C}=-28.3 \pm 0.7 \%\right.$ o relative to the bulk OM and sea ice-derived $\mathrm{IP}_{25}$.

\subsection{Sediment samples}

Carbon isotope analysis was carried out on a number of individual biomarkers identified in hydrocarbon extracts obtained from surface sediments (box cores) collected from across the Canadian High Arctic (Fig. 2). A limited number of downcore analyses were also performed on sediments where trigger weight and/or piston cores were available (e.g. ARC-3 to ARC-5). The $\delta^{13} \mathrm{C}$ values for individual HBIs and $n$-alkanes are summarized in Table 1 . In all cases, the sea ice biomarker, $\mathrm{IP}_{25}$, was the most abundant of the HBI isomers as previously reported (Belt et al., 2007), and GC/MS chromatograms of the hydrocarbon fractions were dominated by this biomarker and a series of $n$-alkanes (typically $\mathrm{C}_{16}-\mathrm{C}_{31}$; Fig.3). For the surface sediments, the $\delta^{13} \mathrm{C}$ values for $\mathrm{IP}_{25}$ ranged from -16.3\% (NOW-2) to $-23.2 \%$ (ARC-6) with a mean value of $-19.3 \pm 2.3 \%$ for all samples analyzed $(n=56)$. Individual 
downcore $\delta^{13} \mathrm{C}$ values for $\mathrm{IP}_{25}$ from $\mathrm{ARC}-3$ showed little variation from the mean value of $-18.5 \pm 0.7 \%$, which was the same as in the surface sample obtained from a box core. Similarly, the mean $\delta^{13} \mathrm{C}$ values for $\mathrm{IP}_{25}$ in downcore samples from ARC-4 $(-18.6 \%)$ and ARC-5 (-18.8\%o) were found to be similar to the mean $\delta^{13} \mathrm{C}$ value found for ARC-3, although a somewhat greater spread in individual values was observed (Table 1). Some variation in $\delta^{13} \mathrm{C}$ values was noted, however, for $\mathrm{IP}_{25}$ extracted from sediments from the North Water (NOW) region and other locations in northern Baffin Bay and west Greenland. $\mathrm{IP}_{25}$ was found to be lighter in both $\mathrm{ARC}-1\left(\delta^{13} \mathrm{C}=-20.7 \%\right)$ and ARC-2 $\left(\delta^{13} \mathrm{C}=-20.5 \%\right)$ sediments compared to ARC-3 $\left(\delta^{13} \mathrm{C}=-18.5 \%\right)$, but heavier in NOW-1 (-16.9\%o) and NOW-2 (-16.3\%) sediments. $\mathrm{IP}_{25}$ was found to be lightest of all in the ARC-6 sediment, with a $\delta^{13} \mathrm{C}$ value $(-23.2 \%)$ similar to that found for $\mathrm{IP}_{25}$ isolated from sea ice in Franklin Bay $\left(\delta^{13} \mathrm{C}=-22.3 \%\right)$ which is a nearby location (Fig. 2).

For all sediments analyzed, HBI isomers other than the sea ice biomarker $\mathrm{IP}_{25}$ were also found in the hydrocarbon fractions as detected by GC/MS, although they were always present in lower abundances than $\mathrm{IP}_{25}$. For ARC-3 and ARC-4, sufficient quantities of an HBI diene and/or two trienes were present to allow determination of their $\delta^{13} \mathrm{C}$ values and comparison with those of co-occurring $\mathrm{IP}_{25}$. For ARC-3, the diene 2 (Fig. 1) had a $\delta^{13} \mathrm{C}$ value of $-18.2 \%$, virtually identical to that found for $\mathrm{IP}_{25}$ in the same sediment. In contrast, $\delta^{13} \mathrm{C}$ values for diene $\mathbf{2}$ and two trienes ( 3 and $\left.\mathbf{4}\right)$ in ARC-4 sediments were respectively heavier (-17.0\%o) and lighter (-20.4\%o, -23.7\%o) than $\operatorname{IP}_{25}(-18.7 \%)$.

In contrast to these relatively ${ }^{13} \mathrm{C}$-enriched isomers, three other $\mathrm{HBI}$ isomers, that are significantly isotopically 'lighter' than $\mathrm{IP}_{25}$, were detected. Triene 5 (Fig. 1) was present in sediments from ARC-1,2,3 with a mean $\delta^{13} \mathrm{C}$ value of $-37.9 \pm 2.2 \%$, while 
tetraene 6 was found in $\mathrm{ARC}-1,2,5$ with a mean $\delta^{13} \mathrm{C}$ value of $-36.4 \pm 1.3 \%$. A further diene isomer, previously unreported and postulated here to have structure 7 (which is pseudo-homologous to triene 5 and tetraene 6), was detected in ARC-2 and found to be heavily ${ }^{13} \mathrm{C}$-depleted $\left(\delta^{13} \mathrm{C}=-42.2 \%\right.$ ) relative to $\mathrm{IP}_{25}$.

In addition to these HBI biomarkers, a suite of $n$-alkanes was present in each of the sediments analyzed and their $\delta^{13} \mathrm{C}$ values are summarized in Table 1. Although a full range $\left(\mathrm{C}_{16}-\mathrm{C}_{31}\right)$ of hydrocarbons was detectable in each sediment extract by $\mathrm{GC} / \mathrm{MS}$, some individual compounds were too low in concentration for accurate $\delta^{13} \mathrm{C}$ determination. For the lower molecular weight compounds $\left(\mathrm{C}_{21}-\mathrm{C}_{27}\right)$, the mean $\delta^{13} \mathrm{C}$ values for the $n$-alkanes fell in the approximate range of $-30.0 \pm 1.2 \%$ to $-32.0 \pm$ $1.5 \%$, while the $\mathrm{C}_{29}$ and $\mathrm{C}_{31}$ analogues were slightly 'lighter', with mean $\delta^{13} \mathrm{C}$ values of $-33.4 \pm 2.3 \%$ and $-34.1 \pm 1.5 \%$ respectively.

\section{Discussion}

\subsection{Isotopic composition of biomarkers versus bulk organic matter}

Historically, $\delta^{13} \mathrm{C}$ values of bulk $\mathrm{OM}$ have been used to evaluate sources of organic carbon in Arctic sediments (e.g. Fernandes and Sicre, 2000). Typically, these data have been used in conjunction with carbon to nitrogen ratios and biomarker (e.g. $n$ alkanoic acids, $n$-alkanes, sterols) distributions to evaluate relative inputs of terrigenous and marine OM to Arctic sediments (reviewed by Stein and MacDonald, 2004). Amongst the recognized challenges faced when using $\delta^{13} \mathrm{C}$ values of bulk OM for elucidating the relative contributions of individually sourced OM, are the difficulties in identifying unique end member values for the various sources (Stein and Macdonald, 2004), along with the limitations of assigning individual compound 
classes to specific sources. The issue of end member determination is particularly problematic for marine OM. End members $\left(\delta^{13} \mathrm{C}\right)$ for marine derived $\mathrm{OM}$ in the Arctic typically lie within the range of $-19 \%$ o to $-24 \%$ (e.g. Goñi et al., 2000, 2005) although a more extended range of about $-17 \%$ to $-30 \%$ has also been reported (Stein and MacDonald, 2004). Terrigenous organic matter is better defined, with an accepted range $\left(\delta^{13} \mathrm{C}\right)$ of $-26 \%$ to $-28 \%$ (Stein and MacDonald, 2004). Previously, these end members have been used to interpret $\delta^{13} \mathrm{C}$ measurements carried out on bulk sedimentary OM. For example, Schubert and Calvert (2001) measured $\delta^{13} \mathrm{C}$ values for bulk OM obtained from box cores from the central Arctic region ranging from $-21 \%$ to $-23 \%$. Isotopically lighter (-23\% to $-24 \%$ ) profiles were recorded for locations closer to Svalbard, consistent with a higher abundance of terrestrial plant biomarkers (Schubert and Stein, 1997). Similarly, $\delta^{13} \mathrm{C}$ values for OM from the Mackenzie Shelf area and the Bering Strait/Chukchi Sea in the western Arctic have been found to increase with distance offshore, reflecting a higher proportion of marine derived OM (Naidu et al., 2000; Stein and MacDonald, 2004). Goñi et al. (2005) have also determined $\delta^{13} \mathrm{C}$ values for Mackenzie River (-26\%o to -27\%o) and Beaufort Shelf sediments $(-25 \%$ to $-26 \%)$ and showed these to be characteristic of their source materials with an enhanced marine contribution to the shelf sediments, as expected. Forest et al. (2007) reported $\delta^{13} \mathrm{C}$ values for OM obtained from sediment traps deployed on the Mackenzie Shelf. Their data showed little deviation in $\delta^{13} \mathrm{C}$ values from ca. $-26 \%$, even with variations in the relative contributions of marine and terrigenous inputs, indicating that the corresponding end member values were similar. An exception to this uniformity in $\delta^{13} \mathrm{C}$ values was coincident with the spring ice melt, at which point they increased sharply to between $-20 \%$ and $-21 \%$. This was attributed to a significant input of isotopically 'heavy' OM originating from the sea 
ice, consistent with Southern Ocean sea ice observations (Gibson et al., 1999; Thomas et al., 2001; Kennedy et al., 2002). Similar values for $\delta^{13} \mathrm{C}$ (ca. $-25 \%$ ), with ${ }^{13} \mathrm{C}$ enrichment during the late spring $\left(\delta^{13} \mathrm{C}=\right.$ ca. $\left.-21 \%\right)$, were also noted for $\mathrm{OM}$ isolated from sediment traps from the Beaufort Shelf (O’Brien et al., 2006). As such, the $\delta^{13} \mathrm{C}$ data presented here for OM isolated from sediment traps in Franklin Bay are entirely consistent with previous findings reported for other western Canadian Arctic locations. However, in addition, the increases in $\delta^{13} \mathrm{C}$ values for bulk OM obtained from sediment traps observed during the spring ice melt are accompanied by higher abundances of the sea ice biomarker $\mathrm{IP}_{25}$ (Fig. 5) as expected following autochthonous input. At other times, lower abundances of $\mathrm{IP}_{25}$ are likely due to smaller year-round deposition, consistent with additional input of OM from allochthonous sources (Forest et al., 2008). Indeed, there is also greater variation in the baseline $\delta^{13} \mathrm{C}$ values for the Franklin Bay sediment trap OM given here (Fig. 5) compared with those reported previously for the Mackenzie River or Beaufort Shelf samples. This is to be expected since the isotopic composition of bulk OM will be strongly influenced by allochthonous processes such as continental erosion and resuspension of previously deposited OM that are known to occur in Franklin Bay (Forest et al., 2008).

The magnitude of the increase in $\delta^{13} \mathrm{C}$ attributed to sea ice-derived OM noted by Forest et al. (2007), O'Brien et al. (2006) and now in this study, is somewhat smaller than that observed for the related phenomenon in the Southern Ocean (Gibson et al., 1999). This is presumably due to either a lower flux of relatively ${ }^{13} \mathrm{C}$-enriched $\mathrm{OM}$ from the sea ice in the Arctic and/or indicates that the Arctic sea ice OM is less ${ }^{13} \mathrm{C}$ enriched than Antarctic OM. Direct measures of isotopic signatures of OM from Arctic sea ice have been reported only rarely. When studying distributions in $\delta^{13} \mathrm{C}$ 
values of OM in the central Arctic, Schubert and Calvert (2001) made measurements on sea ice, meltwater ponds and surface waters. The ice core samples had $\delta^{13} \mathrm{C}$ values of $-18.3 \%$ to $-20.6 \%$ with values in nearby sediment-free meltwater ponds of $-15.3 \%$. In contrast, filtered surface seawater had values of $-23 \%$ to $-27.6 \%$, although it was noted that these may have been influenced by some contributions from isotopically 'lighter' terrestrial inputs. This highlights further, one of the difficulties in interpreting $\delta^{13} \mathrm{C}$ values from bulk OM. One approach used to address this limitation when investigating the relative inputs to sedimentary $\mathrm{OM}$, is to analyze for source specific biomarkers and, where possible, combine these analyses with compound specific isotopic determinations. For the Arctic, a limited number of studies have adopted this combined approach. For example, Goñi et al. (2005) determined the stable isotopic composition of low molecular weight fatty acids in Mackenzie River sediments and showed them to be substantially ${ }^{13} \mathrm{C}$-depleted $\left(\delta^{13} \mathrm{C}=\right.$ $-36 \%$ to $-40 \%$ ) compared to the corresponding compounds identified in the Beaufort Shelf sediments $\left(\delta^{13} \mathrm{C}=-25 \%\right.$ o to $-29 \%$ ) , consistent with contrasting sources. In a further study, Drenzek et al. (2007) measured the ${ }^{13} \mathrm{C}$ composition of a wider range of fatty acids $\left(\mathrm{C}_{14}-\mathrm{C}_{30}\right)$ and co-occurring $n$-alkanes $\left(\mathrm{C}_{14}-\mathrm{C}_{35}\right)$ from Beaufort Sea sediments. Both the fatty acids $\left(\delta^{13} \mathrm{C}=-25 \%\right.$ to $\left.-33 \%\right)$ and the $n$-alkanes $\left(\delta^{13} \mathrm{C}=\right.$ $-28 \%$ o to $-32 \%$ ) became isotopically 'lighter' with increasing molecular weight, consistent with increased terrestrial plant input. For the Antarctic, Sinninghe Damsté et al. (2007) reported the occurrence and isotopic composition of an HBI diene and a related thiane in sediments from Ellis Fjord. The ${ }^{13} \mathrm{C}$-enrichment of the diene $\left(\delta^{13} \mathrm{C}=\right.$ ca. $-9 \%$ ) and the thiane $\left(\delta^{13} \mathrm{C}=\right.$ ca. $-10 \%$ to $-15 \%$ o $)$ supported an origin from sea ice diatoms for the diene with subsequent formation of the thiane within the sulfidic sediments (Sinninghe Damsté et al., 2007). The same diene had been reported 
previously in mixed sea ice diatom populations from the Antarctic (Nichols et al., 1988; Johns et al., 1999). The co-occurrence of both 'heavy' (e.g. ${ }^{13} \mathrm{C}$-enriched HBI alkene) and 'light' (e.g. ${ }^{13} \mathrm{C}$-depleted sterols) biomarkers within the Ellis Fjord sediments illustrated the additional benefit that analysis by GC/C/IRMS offers when assessing sedimentary inputs of organic chemicals from different sources. Our current study, therefore, utilized this approach with a particular focus on the sea ice biomarker, $\mathrm{IP}_{25}$.

The mean $\delta^{13} \mathrm{C}$ values for $\mathrm{IP}_{25}$ for all our sediment $\left(\delta^{13} \mathrm{C}=-19.3 \%\right)$ and sediment trap $\left(\delta^{13} \mathrm{C}=-19.6 \%\right.$ ) samples lie at the 'heavy' end of the range cited by Goñi et al. (2005) for marine $\mathrm{OM}$, while the values of $-16.9 \%$ and $-16.3 \%$ found for $\mathrm{IP}_{25}$ from NOW-1 and NOW-2 sediments respectively, correspond to the most heavily ${ }^{13} \mathrm{C}$-enriched marine end member for Arctic OM according to Stein and Macdonald (2004). For the $n$-alkanes, our ${ }^{13} \mathrm{C}$ isotope data are comparable to those reported by Drenzek et al. (2007) who measured very similar $\delta^{13} \mathrm{C}$ values for $n$-alkanes extracted from surface sediments from the Beaufort Sea. These authors assigned a predominantly terrigenous source (higher plant waxes and weathering of organic-rich sedimentary rocks) for the $n$-alkanes, and the same origins seem likely here. In any case, whatever the relative terrigenous inputs to these ubiquitous chemicals are, the isotopic signatures of the $n$-alkanes in sediments $\left(\delta^{13} \mathrm{C}=\right.$ ca. $-29 \%$ to $-34 \%$; Table 1$)$ are substantially different from the HBIs described here, especially the sea ice-derived $\mathrm{IP}_{25}$ (ca. $-19 \%$ o to $-22 \%$ ).

\subsection{Major outcomes of the present study}

The principal aim of this paper is to report the isotopic signatures of HBI biomarkers (especially $\mathrm{IP}_{25}$ ), $n$-alkanes and bulk $\mathrm{OM}$ in Arctic sea ice, sediment traps and sediments from seasonally ice-covered locations from the Canadian High Arctic. A 
summary of these isotopic signatures together with related data obtained from literature cited in this paper is shown in Figure 6. The specificity of $\mathrm{IP}_{25}$ to a sea ice origin means that, wherever detected, its isotopic signature should ideally reflect its formation from within this isolated environment. The similarity between the single $\delta^{13} \mathrm{C}$ value for $\mathrm{IP}_{25}$ in sea ice $\left(\delta^{13} \mathrm{C}=-22.3 \%\right.$ ) and the mean $\delta^{13} \mathrm{C}$ values for $\mathrm{IP}_{25}$ analyzed in all sediments $\left(\delta^{13} \mathrm{C}=-19.3 \%\right)$ and sediment trap samples $\left(\delta^{13} \mathrm{C}=-\right.$ $19.6 \%$ ) endorses the proposed uniformity of origin for $\mathrm{IP}_{25}$, and these mean values are consistent with previously reported $\delta^{13} \mathrm{C}$ values for Arctic sea ice $\mathrm{OM}$ which range from $-18.3 \%$ to $-20.6 \%$ (Schubert and Calvert, 2001). The small variations in isotopic composition of $\mathrm{IP}_{25}$ likely reflect the localized sea ice conditions and the influences that these have on diatom growth and isotopic composition of individual lipids. Indeed, we acknowledge that, as presented, there appears a notable difference between the individual $\delta^{13} \mathrm{C}$ value for $\mathrm{IP}_{25}$ in sea ice and its mean value in sediments or sediment trap material. However, the latter are influenced by spatial and time averaging and therefore, such a difference is not too surprising, with the sea ice value reported here representing the 'light' end of the full range for $\mathrm{IP}_{25}$. We also note that the $\delta^{13} \mathrm{C}$ value for $\mathrm{IP}_{25}$ in sea ice $\left(\delta^{13} \mathrm{C}=-22.3 \%\right.$ ), although 'lighter' than the mean sediment and sediment trap values, compares well with the corresponding value $\left(\delta^{13} \mathrm{C}\right.$ $=-23.2 \%$ ) obtained for sedimentary material from a similar location. Confirmation of whether, for example, $\mathrm{CO}_{2}$ concentrations, temperature, diatom growth rates or a combination of these contribute to determining the isotopic compositions of individual lipids and of bulk sea ice OM will require analysis of a greater number of sea ice samples from different locations in the future, with parallel measurements of such parameters. 
What is also clear from this study, is that the mean $\delta^{13} \mathrm{C}$ signature of $\mathrm{IP}_{25}$ (ca. -20\%), whilst substantially 'heavier' than that of Arctic planktonic marine OM (e.g. $n$ - $\mathrm{C}_{21: 6}$; $\delta^{13} \mathrm{C}=-28.3 \pm 0.7 \%$ ), is 'lighter' than the majority of the $\delta^{13} \mathrm{C}$ values reported previously for sea ice OM in the Antarctic (Gibson et al., 1999; Thomas et al., 2001; Kennedy et al., 2002). However, McMinn et al. (1999) showed that the ${ }^{13} \mathrm{C}$-enrichment in sea ice $\mathrm{OM}$ was lowest at the ice-water interface $\left(\delta^{13} \mathrm{C}=-18.0 \%\right)$, while Thomas et al. (2001) noted that $\delta^{13} \mathrm{C}$ values for sediment trap OM collected below platelet ice did not show the same ${ }^{13} \mathrm{C}$-enrichment as that found for trap OM below sheet sea ice (Gibson et al., 1999), possibly due to a less 'closed' environment for the former. The same effect may be responsible for the observed relatively 'light' values described here for Arctic sea ice OM. The magnitude of the $\delta^{13} \mathrm{C}$ values for $\mathrm{IP}_{25}$ are consistent, however, with our measurements on bulk OM in sediment traps, with an increase in $\delta^{13} \mathrm{C}$ values observed during the spring ice melt to ca. $-23.5 \%$. The benefit of carrying out compound specific isotopic analysis using GC/C/IRMS is further illustrated by consideration of our data for the various HBI isomers.

Specifically, diene $\mathbf{2}$ and triene $\mathbf{3}$, which are pseudohomologous with $\operatorname{IP}_{25}(\mathbf{1})$, were found to have similar isotopic compositions to $\mathrm{IP}_{25}$ and are likely derived from a common source for the samples studied here, even though these isomers are not restricted to a sea ice origin in all environments. Indeed, the small differences observed between $\delta^{13} \mathrm{C}$ values for diene $\mathbf{2}$, triene $\mathbf{3}$ and $\mathrm{IP}_{25}$ may, in part, be due to some allochthonous input from e.g. open-water planktonic diatom species. In contrast to these relatively ${ }^{13} \mathrm{C}$-enriched $\mathrm{HBIs}$, the isomeric diene 7, triene 5 and tetraene $\mathbf{6}$ were all substantially depleted in ${ }^{13} \mathrm{C}\left(\delta^{13} \mathrm{C}=-35.0 \%\right.$ to $-42.2 \%$, suggesting they result from an entirely different origin, possibly from freshwater diatoms. These highly depleted $\delta^{13} \mathrm{C}$ signatures are more typical of the lipids of freshwater algae as 
previously reported for long chain fatty acids (Goñi et al., 2005). Previously, we have reported on the presence of both triene 5 and tetraene $\mathbf{6}$ in the benthic diatom Pleurosigma intermedium W. Smith (Belt et al., 2000a) and 6 in a planktonic species within the Pleurosigma genus (Belt et al., 2001c). A geometric isomer, 8 , of triene $\mathbf{5}$ has been reported in the planktonic diatom Rhizosolenia setigera Brightwell (Belt et al., 2002; Massé et al., 2004) and in sea ice (Belt et al., 2007), and the corresponding tetraene isomer (9) has been found in R. setigera (Belt et al., 2002; Massé et al., 2004) and the freshwater species Navicula sclesvicensis Grunow (Belt et al., 2001b), but both of these isomers were absent from the sediments described here. Thus, while the exact sources of triene $\mathbf{5}$ and tetraene $\mathbf{6}$ remain uncertain at this point, their absence from sea ice samples and their isotopically very 'light' $\delta^{13} \mathrm{C}$ values presented here, certainly argue against a sea ice origin.

Our $\delta^{13} \mathrm{C}$ data for the $n$-alkanes agree with those reported by Drenzek et al. (2007) who measured $\delta^{13} \mathrm{C}$ values for these hydrocarbons from Beaufort Sea sediments, with a general trend towards greater ${ }^{13} \mathrm{C}$-depletion with increasing chain length. Of course, the ubiquity of these $n$-alkanes somewhat limits the interpretation of either abundances or of isotopic composition, but it is interesting to note the clear trends in $\delta^{13} \mathrm{C}$ values observed for these biomarkers between the sea ice, sediment traps and sediments (Fig. 4). The relatively 'light' sedimentary $\delta^{13} \mathrm{C}$ values likely arise from a significant terrigenous input as concluded previously for Beaufort Sea sediments (Drenzek et al., 2007), with a trend towards 'heavier' or more marine-like values from sediments to sediment traps to sea ice (Fig. 4). Given the ubiquity of the $n$-alkanes and the potential for the sea ice to receive some allochthonous inputs from the water column, $\delta^{13} \mathrm{C}$ values for these chemicals in the sea ice samples are unlikely to be truly representative of an autochthonous origin from sea ice biota. As such, extrapolating 
$\delta^{13} \mathrm{C}$ values of specific sea ice biomarkers such as $\mathrm{IP}_{25}$ to represent a 'bulk sea ice' isotopic signature may be more reliable than carrying out isotopic measurements on bulk OM from sea ice directly, since the latter may be influenced by allochthonous inputs. Therefore, the distinctive isotopic signature of $\mathrm{IP}_{25}$ is not only further evidence of its validity as a sea ice proxy but, given the uncertainties in firmly identifying end members for $\delta^{13} \mathrm{C}$ values for Arctic OM from different sources and their subsequent use in calculating percentage source contributions, the identification of a specific sea ice isotopic signature should prove valuable for the interpretation of $\delta^{13} \mathrm{C}$ data from bulk sedimentary $\mathrm{OM}$ which are more routinely available.

\section{Acknowledgements}

This work was supported by grants from the UK Natural Environment Research Council (NE/D013216/1)) and the Seale-Hayne Educational Trust to S.T.B and G.M., ArcticNet (Network of Centers of Excellence of Canada) to L.F. and M.P. and financial support from the Canadian Museum of Nature to M.P. Partial operating funds for the CCGS Amundsen were provided by the International Joint Ventures Fund of the Canada Foundation for Innovation and the Fonds québécois de la recherché sur la nature et les technologies (FQRNT). We thank A. Rochon (ISMERUQAR) and co-workers, for help in obtaining sediment cores. NOW sediment material was provided by the Bedford Institute of Oceanography, Dartmouth, Nova Scotia, Canada. 


\section{References}

Belt, S.T., Cooke, D.A., Robert, J-M., Rowland, S.J., 1996. Structural characterisation of widespread polyunsaturated isoprenoid biomarkers: $\mathrm{A}_{25}$ triene, tetraene and pentaene from the diatom Haslea ostrearia Simonsen. Tetrahedron Letters 37, 4755-4758.

Belt, S.T., Allard, W.G., Massé, G., Robert, J.-M., Rowland, S.J., 2000a. Highly branched isoprenoids (HBIs): Identification of the most common and abundant sedimentary isomers. Geochimica et Cosmochimica Acta 64, 3839-3851.

Belt, S.T., Allard, W.G., Rintatalo, J., Johns, L.A., van Duin, A.C.T., Rowland, S.J., 2000b. Clay and acid catalysed isomerisation and cyclisation reactions of highly branched isoprenoid (HBI) alkenes: implications for sedimentary reactions and distributions. Geochimica et Cosmochimica Acta 64, 3337-3345.

Belt, S.T., Allard, W.G., Massé, G., Robert, J.-M., Rowland, S.J., 2001a. Structural characterisation of $\mathrm{C}_{30}$ highly branched isoprenoid alkenes (rhizenes) in the marine diatom Rhizosolenia setigera. Tetrahedron Letters 42, 5583-5585.

Belt, S.T., Massé, G., Allard, W.G., Robert, J.-M., Rowland, S. J., 2001b. Identification of a $\mathrm{C}_{25}$ highly branched isoprenoid triene in the freshwater diatom Navicula sclesvicensis. Organic Geochemistry 32, 1169-1172. 
Belt, S.T., Massé, G., Allard, W.G., Robert, J.-M., Rowland, S.J., 2001c. C25 highly branched isoprenoid alkenes in planktonic diatoms of the Pleurosigma genus. Organic Geochemistry 32, 1271-1275.

Belt, S.T., Massé, G., Allard, W.G., Robert J.-M., Rowland, S.J., 2002. Effects of auxosporulation on distributions of $\mathrm{C}_{25}$ and $\mathrm{C}_{30}$ isoprenoid alkenes in Rhizosolenia setigera. Phytochemistry 59, 141-148.

Belt, S.T., Massé, G., Rowland, S.J., Poulin, M., Michel, C., LeBlanc, B., 2007 A novel chemical fossil of palaeo sea ice: $\mathrm{IP}_{25}$. Organic Geochemistry 38, 16-27.

Blumer, M., Guillard, R.R., Chase, T., 1971. Hydrocarbons of marine phytoplankton. Marine Biology 8, 183-189.

Booth, B.C., Horner, R.A., 1998. Microalgae on the Arctic Ocean Section, 1994: species abundance and biomass. Deep-Sea Research II 44, 1607-1622.

Drenzek, N.J., Montlucon, D.B., Yunker, M.B., Macdonald, R.W., Eglinton, T.I., 2007. Constraints on the origin of sedimentary organic carbon in the Beaufort Sea from coupled molecular ${ }^{13} \mathrm{C}$ and ${ }^{14} \mathrm{C}$ measurements. Marine Chemistry 103, 146-162.

Fernandes, M.B., Sicre, M.-A., 2000. The importance of terrestrial organic carbon inputs on Kara Sea shelves as revealed by $n$-alkanes, OC and $\delta^{13} \mathrm{C}$ values. Organic Geochemistry 31, 363-374. 
Fischer, G., 1991. Stable carbon isotope ratios of plankton carbon and sinking organic matter from the Atlantic sector of the Southern Ocean. Marine Chemistry 35, 581-596.

Forest, A., Sampei, M., Hattori, H., Makabe, R., Sasaki, H., Fukuchi, M., Wassman, P., Fortier, L., 2007. Particulate organic carbon fluxes on the slope of the Mackenzie Shelf (Beaufort Sea): Physical and biological forcing of shelf-basin exchanges. Journal of Marine Systems 68, 39-54.

Forest, A., Sampei, M., Makabe, R., Sasaki, H., Barber, D.G., Gratton, Y., Wassman, P., Fortier, L., 2008. The annual cycle of particulate organic carbon export in Franklin Bay (Canadian Arctic): Environmental control and food web implications. Journal of Geophysical Research 113, C03S05.

Gibson, J.A.E., Trull, T., Nicholls, P.D., Summons, R.E., McMinn, A. 1999. Sedimentation of ${ }^{13} \mathrm{C}$-rich organic matter from Antarctic sea-ice algae: A potential indicator of past sea-ice extent. Geology 27, 331-334.

Goñi, M.A., Yunker, M.B., Macdonald, R.W., Eglinton, T.I., 2000. Distribution and sources of organic biomarkers in Arctic sediments from the Mackenzie River and Beaufort Shelf. Marine Chemistry 71, 23-51.

Goñi, M.A., Yunker, M.B., Macdonald, R.W., Eglinton, T.I., 2005. The supply and preservation of ancient and modern components of organic carbon in the Canadian Beaufort Shelf of the Arctic Ocean. Marine Chemistry 93, 53-73. 
Grossi, V., Beker, B., Geenevasen, J.A.J., Schouten, S., Raphel, D., Fontaine, M.-F., Sinninghe Damsté, J.S., 2004. C $25_{25}$ highly branched isoprenoid alkenes from the marine benthic diatom Pleurosigma strigosum. Phytochemistry 65, 3049-3055.

Johns, L., Wraige, E.J., Belt, S.T., Lewis, C.A., Massé, G., Robert, J.-M., Rowland, S.J., 1999. Identification of $\mathrm{C}_{25}$ highly branched isoprenoid (HBI) dienes in Antarctic sediments, sea-ice diatoms and laboratory cultures of diatoms. Organic Geochemistry $30,1471-1475$.

Kennedy, H., Thomas, D.N., Kattner, G., Haas, C., Dieckmann, G.S., 2002. Particulate organic matter in Antarctic summer sea ice: concentration and stable isotopic composition. Marine Ecology Progress Series 238, 1-13.

Massé, G., Belt, S.T., Rowland, S.J., Rohmer, M. 2004. Isoprenoid biosynthesis in the diatoms Rhizosolenia setigera (Brightwell) and Haslea ostrearia (Simonsen).

Proceedings of the National Academy of Sciences of the United States of America 101, 4413-4418.

Massé, G., Rowland, S.J., Sicre, M.-A., Jacob, J., Jansen, J., Belt, S.T., 2008. Abrupt climate changes for Iceland during the last millennium: Evidence from high resolution sea ice reconstructions. Earth and Planetary Science Letters 269, 564-568.

McMinn, A., Skerratt, J., Trull T., Ashworth C., Lizotte, M., 1999. Nutrient stress gradient in the bottom $5 \mathrm{~cm}$ of fast ice, McMurdo Sound, Antarctica. Polar Biology 21, $220-227$. 
Naidu, A.S., Cooper, L.W., Finney, B.P., Macdonald, R.W., Alexander, C., Semiletov, I.P., 2000. Organic carbon isotope ratios $\left(\delta^{13} \mathrm{C}\right)$ of Arctic Amerasian Continental shelf sediments. International Journal of Earth Sciences 89, 522-532.

Nichols, P.D., Volkman, J.K., Palmisano, A.C., Smith, G.A., White, D.C., 1988.

Occurrence of an isoprenoid $\mathrm{C}_{25}$ diunsaturated alkene and high neutral lipid content in Antarctic sea-ice diatom communities. Journal of Phycology 24, 90-96.

O’Brien, M.C., Macdonald, R.W., Melling, H., Iseki, K., 2006. Particle fluxes and geochemistry on the Canadian Beaufort Shelf: Implications for sediment transport and deposition. Continental Shelf Research 26, 41-81.

Pancost, R.D., Freeman, K.H., Wakeham, S.G., Robertson, C.Y., 1997. Controls on carbon isotope fractionation by diatoms in the Peru Upwelling Region. Geochimica Cosmochimica Acta 61, 4983-4991.

Popp B.N., Laws E.A., Bidigare R.R., Dore J.E., Hanson K.L., Wakeham S.G., 1998 Effect of phytoplankton cell geometry on carbon isotopic fractionation. Geochimica Cosmochimica Acta 62, 69-77.

Poulin, M., 1990. Ice diatoms: the Arctic. In: Medlin, L.K., Priddle, J. (Eds.), Polar Marine Diatoms. British Antarctic Survey, Cambridge, pp. 15-18. 
Rau, G.H., Sullivan, C.W., Gordon, L.I., 1991. $\delta^{13} \mathrm{C}$ and $\delta^{13} \mathrm{~N}$ variations in Weddell Sea particulate organic matter. Marine Chemistry 35, 355-369.

Robson, J.N., Rowland S.J., 1986. Identification of novel widely distributed sedimentary acyclic sesterterpenoids. Nature 324, 561-563.

Robson, J.N., Rowland, S.J., 1988. Biodegradation of highly branched isoprenoid hydrocarbons: A possible explanation of sedimentary abundance. Organic Geochemistry $13,691-695$.

Rowland, S.J., Belt, S.T., Wraige, E.J., Massé, G., Roussakis, C., Robert, J.-M. 2001. Effects of temperature on polyunsaturation in cytostatic lipids of Haslea ostrearia. Phytochemistry 56, 597-602.

Rowland, S.J., Robson, J.N., 1990. The widespread occurrence of highly branched acyclic $\mathrm{C}_{20}, \mathrm{C}_{25}$ and $\mathrm{C}_{30}$ hydrocarbons in recent sediments and biota - a review. Marine Environmental Research 30, 191-216.

Schubert, C.J., Calvert, S.E., 2001. Nitrogen and carbon isotopic composition of marine and terrestrial organic matter in Arctic Ocean sediments: implications for nutrient utilization and organic matter composition. Deep Sea Research I 48, 789-810.

Sinninghe Damsté, J.S., Rijpstra, W.I.C., Schouten, S., Peletier, H., van der Maarel, M.J.E.C., Gieskes, W.W.C., 1999. Structural identification of the $\mathrm{C}_{25}$ highly branched 
isoprenoid pentaene in the marine diatom Rhizosolenia setigera. Organic Geochemistry $30,1581-1583$.

Sinninghe Damsté, J.S., Muyzer,G., Abbas,B., Rampen, S.W., Massé, G., Allard, W.G., Belt, S.T., Robert, J-M., Rowland, S.J., Moldowan, J.M., Barbanti, S.M., Fago, F.J., Denisevich, P., Dahl, J., Trindade, L.A.F., Schouten, S. 2004. The rise of the rhizosolenid diatoms. Science 304, 584-587.

Sinninghe Damsté, J.S., Rijpstra, W.I.C., Coolen, M.J.L, Schouten, S., Volkman, J.K., 2007. Rapid sulfurisation of highly branched isoprenoid (HBI) alkenes in sulfidic Holocene sediments from Ellis Fjord, Antarctica. Organic Geochemistry 38, 128-129.

Stein, R., Macdonald, R.W., 2004. The Organic Carbon Cycle in the Arctic Ocean. Springer, Berlin.

Thomas, D.N., Kennedy, H., Kattner, G., Gerdes, D., Gough, C., Dieckmann, G.S., 2001. Biogeochemistry of platelet ice: its influence on particle flux under fast ice in the Weddell Sea, Antarctica. Polar Biology 24, 486-496.

Volkman, J.K., Barrett, S.M., Dunstan, G.A., 1994. $\mathrm{C}_{25}$ and $\mathrm{C}_{30}$ highly branched isoprenoid alkenes in laboratory cultures of two marine diatoms. Organic Geochemistry $21,407-414$. 
Wada, E., Terazaki, M., Kabaya, Y., Nemoto, T., 1987. ${ }^{15} \mathrm{~N}$ and ${ }^{13} \mathrm{C}$ abundances in the Antarctic Ocean with emphasis on the biogeochemical structure of the food web. Deep Sea Research 34, 829-841.

Wraige, E.J., Belt, S.T., Lewis, C.A., Cooke, D.A., Robert, J-M., Massé, G., Rowland, S.J., 1997. Variations in structures and distributions of $\mathrm{C}_{25}$ highly branched isoprenoid (HBI) alkenes in cultures of the diatom, Haslea ostrearia (Simonsen). Organic Geochemistry 27, 497-505.

Wraige, E.J., Belt, S.T., Massé, G., Robert, J.-M., Rowland, S.J., 1998. Variations in distributions of $\mathrm{C}_{25}$ highly branched isoprenoid (HBI) alkenes in the diatom, Haslea ostrearia: influence of salinity. Organic Geochemistry 28, 855-859.

Yunker, M.B., Macdonald, R.W., Veltkamp, D.J., Cretney, W.J., 1995. Terrestrial and marine biomarkers in a seasonally ice-covered Arctic estuary - integration of multivariate and biomarker approaches. Marine Chemistry 49, 1-50. 


\section{Figure and Table Legends}

Figure 1. Chemical structures of highly branched isoprenoid (HBI) alkenes described in the current study. $\mathrm{IP}_{25}$ : 1; Dienes: $\mathbf{2 , 7}$; Trienes: $\mathbf{3 , 4 , 5 , 8}$; Tetraenes: $\mathbf{6 , 9}$.

Figure 2. Map of sampling locations for sea ice, sediment trap and sediment samples. Individual numbering corresponds to specific locations cited in the text.

Figure 3. Representative partial GC/MS chromatograms of extracts obtained from sea ice, sediment trap material (May 2005) and box core sediment from Franklin Bay. Selected $n$-alkanes $\left(\mathrm{C}_{19}-\mathrm{C}_{24}\right)$ are denoted by solid circles. The peak labeled $*$ is due to $\mathrm{IP}_{25}$.

Figure 4. $\delta^{13} \mathrm{C}$ values for $n$-alkanes $\left(\mathrm{C}_{19}-\mathrm{C}_{31}\right)$ and $\mathrm{IP}_{25}$ from sea ice, sediment traps and sediments from the Canadian High Arctic. The magnitudes of the standard deviations for each dataset ( $n$-alkanes) are indicated by the $\pm \sigma$ entries.

Figure 5. Seasonal variations in the $\mathrm{IP}_{25}$ abundances (open circles) and $\delta^{13} \mathrm{C}$ profiles for bulk organic material (triangles) and $\mathrm{IP}_{25}$ (solid circles) in sediment trap material from Franklin Bay (August 2004 - July 2005).

Figure 6. Summary of $\delta^{13} \mathrm{C}$ values for bulk organic matter and individual biomarkers described in the text: (a) experimental data obtained in the current study; (b) literature data cited in the text. Ranges in $\delta^{13} \mathrm{C}$ values correspond to high/low limits rather than statistical variations from a mean in order to enable comparison with literature ranges. 
Table 1. Summary of $\delta^{13} \mathrm{C}$ values for individual biomarkers described in the current study. For sediments, individual core horizons are designated by depth and core type (BC: Box Core; TWC: Trigger Weight Core; PC: Piston Core). 